\title{
EVALUATION OF THE NONALCOHOLIC FAT LIVER DISEASE FIBROSIS SCORE FOR PATIENTS UNDERGOING BARIATRIC SURGERY
}

\author{
Silvania Klug PIMENTEL ${ }^{1,5}$, Rodrigo STROBEL ${ }^{2}$, Carolina Gomes GONÇALVES ${ }^{3}$, \\ Danielle Giacometti SAKAMOTO ${ }^{4}$, Flávio Heuta IVANO5 ${ }^{5}$ and Júlio Cezar Uili COELHO 6
}

\begin{abstract}
Context - Morbidly obese patients have an increased risk for nonalcoholic fat liver disease. Its severe form, nonalcoholic steatohepatitis may cause liver fibrosis. The diagnosis of advanced fibrosis has great value during the pre operative evaluation for bariatric surgery. Currently, liver biopsy is the gold standard for diagnosis of liver fibrosis. Objective - To evaluate the nonalcoholic fat liver disease fibrosis score in morbidly obese patients undergoing Roux-en-Y gastric bypass in our population. Methods - One hundred fifty-eight morbidly obese patients that had undergone bariatric surgery were included. Age, body mass index, hyperglycemia, platelet count, albumin and AST/ALT ratio were applied to the score formula. Scores above 0.676 were indicative of advanced liver fibrosis and scores under $-1,455$ absence of advanced liver fibrosis. These scores were compared to liver biopsy findings. Results - The presence of advanced fibrosis could be diagnosed with good accuracy, with a positive predictive value of $83.7 \%$. The score had a higher accuracy to exclude advanced fibrosis with a negative predictive value of $97 \%$. Twenty-five patients (16\%) had scores between the cutoffs points and were identified as indeterminate. The score sensibility and specificity was $83 \%$ and $97 \%$ respectively. Conclusions - The nonalcoholic fat liver disease fibrosis score has high accuracy to identify and exclude advanced liver fibrosis in morbidly obese patients subjected to bariatric surgery.
\end{abstract}

HEADINGS - Liver cirrhosis. Fatty liver. Obesity, morbid. Bariatric surgery.

\section{INTRODUCTION}

The increasing prevalence of obesity, diabetes and metabolic syndrome promoted nonalcoholic fat liver disease (NAFLD) to the most common cause of chronic liver disease worldwide ${ }^{(4,7,18,29)}$. In the United States, the incidence of obesity (class II and III) has increased from $23 \%$ to $30 \%$, and in Brazil, $40.6 \%$ of the population are overweight, and $10 \%$ are obese ${ }^{(11,25)}$. The prevalence of NAFLD in the USA population is 30\% and in patients undergoing bariatric surgery is $90 \%(5,17$, ${ }^{21,28)}$. The incidence of nonalcoholic steatohepatitis in morbidly obese patients approaches $70 \%$, and $4 \%$ of them may have cirrhosis ${ }^{(5,20,24,36)}$. Mild steatosis, in the majority of cases, remains stable without any further complication $^{(15,38)}$. However, patients with fibrosis have a higher risk for cirrhosis, portal hypertension, hepatocarcinoma and death ${ }^{(1,2,9,10,32,34,38)}$. Therefore, identifying the presence and severity of liver fibrosis in patients with NAFLD is crucial in the guidance of subsequent management. Most of the patients with fibrosis do not have symptoms and there are no specific laboratory tests to detect liver fibrosis to date. Liver biopsy remains the only way to determine fibrosis' grade and prognosis, but this is an invasive procedure and can be associated with a number of complications ${ }^{23}$ 30). A noninvasive score, the NAFLD fibrosis score, was recently created and it is in the validation process. This score is based on routinely measured clinical and laboratory variables and was initially used in a population of obese patients and was able to separate patients with and without significant NAFLD.

The purpose of this study was to evaluate de NAFLD fibrosis score in a group of morbidly obese patients undergoing bariatric surgery.

\section{METHODS}

One hundred and fifty-eight patients with morbid obesity that had undergone bariatric surgery were retrospectively evaluated. The indication for the bariatric surgery followed the Brazilian "Conselho Federal de

Post Graduation Course on Surgery of the Federal University of Paraná and Gastrovida Bariatric Surgery Service, Curitiba, PR, Brasil.

${ }_{1}^{1}$ Post Graduation Course on Surgery, Federal University of Paraná, Curitiba, PR; ${ }^{2}$ Bariatric Surgery Service, Clinica GastroVida, Curitiba, PR; ${ }^{3}$ General Surgery Department, Positivo University; ${ }^{4}$ Pathology Department, Evangelic Medical School, Curitiba, PR; ${ }^{5}$ Bariatric Surgery Service, Sugisawa Medical Center, Curitiba, PR; ${ }^{6}$ Division of Gastrointestinal Surgery, Hospital de Clínicas, Federal University of Paraná, Curitiba, PR, Brazil.

Correspondence: Dr. Silvania K. Pimentel - Avenida Iguaçu, 1236 - sala 115 - 80250-190 - Curitiba, PR, Brazil. 
Medicina's" criteria: body mass index (BMI) over $40 \mathrm{~kg} / \mathrm{m}^{2}$ or over $35 \mathrm{~kg} / \mathrm{m}^{2}$ with complications due to the obesity, such as diabetes, sleep apnea, high blood pressure, coronary disease and others ${ }^{(6)}$.

During the pre operative evaluation, a complete history and physical examination was undertaken to exclude other causes of liver disease other than obesity. Laboratory evaluation included routine liver biochemistry (AST and ALT levels, total bilirubin, albumin, alkaline phosphatase and gamma-glutamyl transpeptidase), complete blood count, total cholesterol, HDL cholesterol and total triglycerides, fasting glucose, viral serology for hepatitis B and C, and anti mitochondrial antibody.

At the time of Roux-em-Y gastric bypass, patients routinely underwent wedge liver biopsy at the end of the bariatric procedure. Liver biopsies were routinely stained with hematoxylin and eosin and Gomori's trichrome. A single liver pathologist, who did not have access to the clinical history nor to the fibrosis score, read the biopsies. The histological fibrosis stage was scored based on the 5- point scale proposed by Brunt ${ }^{(8)}$, and modified by Kleiner et al. ${ }^{(26)}$ (Table 1).

TABLE 1 . Histological fibrosis stage by Brunt ${ }^{(8)}$, and modified by Kleiner et al. ${ }^{(26)}$

\begin{tabular}{lc}
\hline & Fibrosis stage \\
\hline Absence of fibrosis & 0 \\
Portal/perisinusoidal & 1 \\
Perisinusoidal and portal/periportal & 2 \\
Septal or bridging fibrosis & 3 \\
Cirrhosis & 4 \\
\hline
\end{tabular}

The NAFLD fibrosis score was calculated using the Angulo's et al. ${ }^{(3)}$ formula based on six variables: NAFLD score: $1,675+0,037 \mathrm{x}$ age (years) $+0,094 \mathrm{x}$ BMI $\left(\mathrm{kg} / \mathrm{m}^{2}\right)$ $+1,13 \times \mathrm{IFG} /$ diabetes $($ yes $=1$, no $=0)+0,99 \times$ AST/ALT ratio $-0,013 \times$ platelet $(109 / \mathrm{L})-0,66 \mathrm{x}$ albumin $(\mathrm{g} / \mathrm{dL})$. Two cutoff points previously validated were used: values lower than -1.455 exclude advanced fibrosis (grade III and IV), and values above 0,676 indicate the presence of advanced fibrosis.

Continuous variables were expressed by mean and standard deviation and categorical variables by percentage. The NAFLD fibrosis score accuracy was determined by calculating sensitivity, specificity, positive predictive value, negative predictive value and likelihood ratios taking into consideration the prevalence of advanced liver fibrosis in the studied group. All analysis were carried out using the statistical analysis software Prism 5 (Graphpad, San Diego, CA).

\section{RESULTS}

Patient population: 158 patients were analyzed and the mean age was 36 years ( \pm 10 years), and $77 \%$ were females. All patients had a BMI greater than $35 \mathrm{~kg} / \mathrm{m}^{2}$, the mean BMI was $41 \mathrm{~kg} / \mathrm{m}^{2}\left( \pm 5 \mathrm{~kg} / \mathrm{m}^{2}\right)$. Type II diabetes or fasting glucose level greater than $110 \mathrm{mg} / \mathrm{dL}$ was present in $16 \%$ of the patients. Table 2 summarizes demographic and clinical data.
TABLE 2. Characteristics of the patient population

\begin{tabular}{lcc}
\hline & Mean $(\mathrm{SD})$ & Reference values \\
\hline Age (years) & $36 \pm 10$ anos & \\
Gender (female/male) & $122 / 36$ & \\
BMI & $41 \pm 5$ & \\
ALT & $38 \pm 29,5$ & $<55 \mathrm{U} / \mathrm{L}$ \\
AST & $30,1 \pm 17,7$ & $5-43 \mathrm{U} / \mathrm{L}$ \\
Albumin & $4,2 \pm 0,42$ & \\
Platelet count & $279.000 \pm 73000$ & $150000-450000 / \mathrm{uL}$ \\
DM II (yes) & $26(16 \%)$ & \\
Portal areas & $15 \pm 5$ & \\
Fibrosis stage $(0 / 1 / 2 / 3 / 4)$ & $12 / 48 / 76 / 19 / 3$ & \\
\hline
\end{tabular}

$\mathrm{SD}=$ standard deviation; $\mathrm{BMI}=$ body mass index; $\mathrm{ALT}=$ alanine aminotransferase; $\mathrm{AST}=$ aspartate aminotransferase; $\mathrm{DM}$ II= diabetes mellitus II

Histological analysis: all biopsies were $10 \mathrm{~mm}$ in length and the number of portal areas were $15 \pm 6$. The samples were from the liver wedge and to avoid fibrosis overestimation, the subcapsular fibrosis was not considered in the evaluation process. The criteria for the diagnosis of NAFLD was found in all biopsies samples and only $12(8 \%)$ did not have fibrosis. From $146(92 \%)$ with fibrosis, stage 2 was the most frequent and it was present in 76 patients $(48 \%)$, followed by fibrosis stage 1 present in 48 patients $(30 \%)$, and advanced liver fibrosis (stage 3 and 4 ) in 22 patients (14\%).

NAFLD score application: 2 cutoff points previously validated were selected to identify the presence (score greater than 0.676) and absence (score lower than -1.455) of significant fibrosis ${ }^{(3)}$. The accuracy calculation took into consideration the prevalence of advanced fibrosis of $14 \%$. The absence and the presence of advanced fibrosis were predicted in $133(84 \%)$ of the patients and in $129(97 \%)$ it was correct. Only $4(2,5 \%)$ were incorrectly graded. In $25(16 \%)$ the score was between the cutoff points and were considered indeterminate, in this group only 1 patient had advanced fibrosis. By applying the low cutoff point (score below - 1.455) 109 (80.1\%) of the 136 patients without advanced fibrosis were correctly staged. Only 1 patient $(0.9 \%)$ of the 110 patients with the score below the low cutoff point was incorrectly staged. Thus, the advanced fibrosis was excluded with high accuracy (negative predictive value of $97.2 \%$ ). By applying a high cutoff point (score above $0.676), 20(87 \%)$ of the 22 patients with advanced fibrosis were correctly staged and only $3(13 \%)$ with scores higher than the high cutoff point were incorrectly staged. The presence of advanced fibrosis was diagnosed with good accuracy (positive predictive value of $81.8 \%$ ). The score sensibility and specificity was $83 \%$ and $97 \%$ respectively. The positive likelihood ratio was 27.6 , thus the probability of a patient with a score higher than 0.676 to have advanced fibrosis is 27.6 times higher than for a patient with no score for advanced fibrosis. Table 3 and 4 summarizes these findings.

TABLE 3. Fibrosis score and histological fibrosis score

\begin{tabular}{lcccc}
\hline Histology/score & $<-1.455$ & $<-1.455$ and 0.676 & $>0.676$ & Total \\
\hline $\begin{array}{l}\text { Mild fibrosis } \\
\text { FO, F1, F2 }\end{array}$ & 109 & 24 & 3 & 136 \\
$\begin{array}{l}\text { Advanced fibrosis } \\
\text { F3 and F4 }\end{array}$ & 1 & 1 & 20 & 22 \\
\hline
\end{tabular}


TABLE 4. Predictive value of the scoring system, taking in consideration the advanced fibrosis prevalence

\begin{tabular}{lc}
\hline & Results \\
\hline Advanced fibrosis prevalence & $14 \%$ \\
Sensibility & $83 \%$ \\
Especificity & $97 \%$ \\
Positive predictive value & $81,2 \%$ \\
Negative predictive value & $97,2 \%$ \\
Likelihood ratio & 27,6 \\
\hline
\end{tabular}

\section{DISCUSSION}

With the increasing prevalence of obesity worldwide, NAFLD has became the most common cause of liver disease in developed countries ${ }^{(11)}$. The majority of patients with morbid obesity, presents NAFLD complicated by fibrosis ${ }^{20,24,36)}$. Our results showed a rate of $92 \%$ of fibrosis in morbidly obese patients subjected to Roux-en-Y gastric bypass. Brazilian data from patients undergoing bariatric surgery showed a wide range of fibrosis rate from $25 \%$ up to $89,5 \%$ in wedge biopsies $^{(14,16,17,19)}$. This variation is probably due to different diagnostic histological criteria ${ }^{(17)}$.

The identification of fibrosis is essential for the prognosis of liver disease and can be done using a panel of markers or scores instead of liver biopsy. These scores have became more accurate than liver biopsy which sometimes is not representative of the real fibrosis grade due to sample error or inadequate amount of tissue ${ }^{(13,35)}$. Scores based on serum markers give a better estimation of the disease in the hepatic tissue $^{(33)}$.

Many fibrosis scores had already been evaluated mostly for hepatitis C patients ${ }^{(12,31,39)}$. For NAFLD patients, the Original European Liver Fibrosis test, which consist of age, tissue inhibitor of matrix metalloproteinase 1, hyaluronic acid and aminoterminal peptide of pro-collagen III, and its variant the Enhanced Liver Fibrosis panel, which uses the same variants except the age, had a good performance in distinguishing patients with fibrosis, moderate fibrosis and severe fibrosis ${ }^{(22)}$. The limitation for the routine use of these scores is the cost and availability of these specific markers.

This study demonstrated the application of the NAFLD score, based on simple clinical and biochemical parameters, in the morbid obese patient group. The absence and the presence of advanced fibrosis were predicted in $133(84 \%)$ of the patients and in $129(97 \%)$ it was correct. Only $4(2,5 \%)$ were incorrectly graded. In $25(16 \%)$ the score was between the cutoff points and were considered indeterminate, in this group only 1 patient had advanced fibrosis. This implies that by applying the NAFLD fibrosis score the liver biopsy could have been avoided in $84 \%$ of patients.

The majority of patients undergoing bariatric surgery did not present advanced fibrosis, 136 or $86 \%$, so the low cutoff point of -1.455 was very accurate to exclude this form of fibrosis with a good negative predictive value of $97.2 \%$. However, the positive predictive value of the high cutoff point of 0.676 was $83.7 \%$, probably due to the low prevalence of advanced fibrosis, only $14 \%$ of the patients.

The NAFLD fibrosis score can be used in pre operative evaluation of patients undergoing bariatric surgery. The great advantage this score is the use of easily obtained variables.

This score is particularly accurate in ruling out the presence of advanced fibrosis. Advanced fibrosis may not reduce in more than $60 \%$ of patients after bariatric surgery, and these patients will have higher risks for cirrhosis and hepatocarcinoma, and they must be followed in the postoperative period ${ }^{(27,37)}$. Also, this group of patients must be informed about the grade of fibrosis and the chance of no regression. The presence of advanced fibrosis do not change the surgical plan, indeed, it is and additional indication for bariatric surgery. However, the surgical procedure must carry out a slow and progressive weight loss since more aggressive bariatric surgery with dramatic weight loss and malnutrition may worse their liver disease.

We conclude that the NAFLD fibrosis score could accurately predict the presence or absence of advanced liver fibrosis in the group of patients undergoing bariatric surgery.

Pimentel SK, Strobel R, Gonçalves CG, Sakamoto DG, Ivano FH, Coelho JCU. Avaliação do escore de fibrose hepática para doença hepática gordurosa não-alcoólica em pacientes submetidos a cirurgia bariátrica. Arq Gastroenterol. 2010;47(2):170-3.

RESUMO - Contexto - Pacientes com obesidade mórbida apresentam risco significativo para doença hepática gordurosa não-alcoólica e para suas formas mais graves, a esteatohepatite e a cirrose hepática. O diagnóstico de tais alterações é importante, principalmente na avaliação pré-operatória de cirurgia bariátrica. Até o momento, a biopsia hepática é o procedimento com maior precisão para tal diagnóstico. Objetivo - Avaliar o escore de fibrose hepática em doença hepática gordurosa não-alcoólica em pacientes com obesidade mórbida na população brasileira. Métodos - Foram incluídos 158 pacientes com obesidade mórbida submetidos a cirurgia bariátrica. Idade, índice de massa corporal, hiperglicemia, albumina, contagem de plaquetas e razão AST/ALT foram aplicados à fórmula do escore de fibrose. Valores acima de 0,676 indicavam fibrose avançada e abaixo de - 1,455 indicavam ausência de fibrose. Estes valores foram comparados com os achados de biopsia hepática realizados no intra-operatório. Resultados - A presença de fibrose avançada foi diagnosticada com boa precisão, valor preditivo positivo de $83,7 \%$. O escore teve melhor precisão para excluir fibrose avançada, com valor preditivo negativo de $97,2 \%$. Em 25 pacientes (16\%) o escore resultou indeterminado entre os pontos de corte. A sensibilidade e a especificidade do escore foram de $83 \%$ e 97\%, respectivamente. Conclusão - O escore de fibrose para doença hepática gordurosa não-alcoólica apresenta elevada precisão para reconhecer e excluir fibrose avançada em pacientes com obesidade mórbida submetidos a cirurgia bariátrica.

DESCRITORES - Cirrose hepática. Fígado gorduroso. Obesidade mórbida. Cirurgia bariátrica. 


\section{REFERENCES}

1. Adams LA, Lymp JF, St Sauver J, Sanderson SO, Lindor KD, Feldstein A, Angulo P. The natural history of nonalcoholic fatty liver disease: a population-based cohort study. Gastroenterology. 2005;129:113-21.

2. Angulo P. Nonalcoholic fatty liver disease. N Engl J Med. 2002;346:1221-31.

3. Angulo P, Hui JM, Marchesini G, Bugianesi E, George J, Farrell GC, Enders F, Saksena S, Burt AD, Bida JP, Lindor K, Sanderson SO, Lenzi M, Adams LA, Kench J, Therneau TM, Day CP. The NAFLD fibrosis score: a noninvasive system that identifies liver fibrosis in patients with NAFLD. Hepatology. 2007;45:846-54

4. Bedogni G, Miglioli L, Masutti F, Tiribelli C, Marchesini G, Bellentani S. Prevalence of and risk factors for nonalcoholic fatty liver disease: the Dionysos nutrition and liver study. Hepatology. 2005;42:44-52.

5. Beymer C, Kowdley KV, Larson A, Edmonson P, Dellinger EP, Flum DR Prevalence and predictors of asymptomatic liver disease in patients undergoing gastric bypass surgery. Arch Surg. 2003;138:1240-4

6. Brasil. Conselho Federal de Medicina. 1766/05 Normas seguras para o tratamento cirúrgico da obesidade mórbida, definindo indicações, procedimentos aceitos e equipe. Brasília, 2005.

7. Browning JD, Szczepaniak LS, Dobbins R, Nuremberg P, Horton JD, Cohen JC, Grundy SM, Hobbs HH. Prevalence of hepatic steatosis in an urban population in the United States: impact of ethnicity. Hepatology. 2004;40:1387-95.

8. Brunt EM. Grading and staging the histopathological lesions of chronic hepatitis the Knodell histology activity index and beyond. Hepatology. 2000;31:241-6.

9. Bugianesi E, Leone N, Vanni E, Marchesini G, Brunello F, Carucci P, Musso A, De Paolis P, Capussotti L, Salizzoni M, Rizzetto M. Expanding the natural history of nonalcoholic steatohepatitis: from cryptogenic cirrhosis to hepatocellular carcinoma. Gastroenterology. 2002;123:134-40.

10. Charlton M. Nonalcoholic fatty liver disease: a review of current understanding and future impact. Clin Gastroenterol Hepatol. 2004;2:1048-58.

11. Clark JM, Brancati FL, Diehl AM. Nonalcoholic fatty liver disease. Gastroenterology. 2002;122:1649-57.

12. Coco B, Oliveri F, Maina AM, Ciccorossi P, Sacco R, Colombatto P, Bonino F, Brunetto MR. Transient elastography: a new surrogate marker of liver fibrosis influenced by major changes of transaminases. J Viral Hepat. 2007;14:360-9.

13. Colloredo G, Guido M, Sonzogni A, Leandro G. Impact of liver biopsy size on histological evaluation of chronic viral hepatitis: the smaller the sample, the milder the disease. J. Hepatol. 2003;39:239-44

14. Cotrim HP, Freitas LA, Alves E, Almeida A, May DS, Caldwell S. Effects of light-to-moderate alcohol consumption on steatosis and steatohepatitis in severely obese patients. Eur J Gastroenterol Hepatol. 2009;21:969-72.

15. Dam-Larsen S, Franzmann M, Andersen IB, Christoffersen P, Jensen LB, Sørensen TIA, Becker U, Bendtsen F. Long term prognosis of fatty liver: risk of chronic liver disease and death. Gut. 2004;53:750-5

16. de Andrade AR, Cotrim HP, Alves E, Soares D, Rocha R, Almeida A, Almeida CG, de Freitas LA. Nonalcoholic fatty liver disease in severely obese individuals: the influence of bariatric surgery. Ann Hepatol. 2008;7:364-8.

17. de Oliveira CP, de Mello ES, Alves VA, Saviero SM, Strauss E. Changes in histological criteria lead to different prevalences of nonalcoholic steatohepatitis in severe obesity. Ann Hepatol. 2007;6:255-61.

18. Fan J, Zhu J, Li X, Chen L, Li L, Dai F, Li F, Chen S. Prevalence of and risk factors for fatty liver in a general population of Shanghai, China. J Hepatol. 2005;43:508-14.

19. Furuya CK Jr, de Oliveira CP, de Mello ES, Faintuch J, Raskovski A, Matsuda M, Vezozzo DC, Halpern A, Garrido AB Jr, Alves VA, Carrilho FJ. Effects of bariatric surgery on nonalcoholic fatty liver disease: preliminary findings after 2 years. J Gastroenterol Hepatol. 2007;22:510-4.

20. Garcia-Monzon C, Martin-Perez E, Iacono OL, Fernandez-Bermejo M, Majano PL, Apolinario A, Larranaga E, Moreno-Otero R. Characterization of pathogenic and prognostic factors of nonalcoholic steatohepatitis associated with obesity. J Hepatol. 2000;33:716-24

21. Gholam PM, Flancbaum L, Machan JT, Charney DA, Kotler DP. Nonalcoholic fatty liver disease in severely obese subjects. Am J Gastroenterol. 2007;102:399408

22. Guha IN, Parkes J, Roderick P, Chattopadhyay D, Cross R, Harris S, Kaye P, BurtAD, Ryder SD, Aithal GP, Day CP, Rosenberg WM. Noninvasive markers of fibrosis in nonalcoholic fatty liver disease: validating the European Liver Fibrosis Panel and exploring simple markers. Hepatology. 2008:47:455-60.

23. Gunneson TJ, Menon KVN, Wiesner RH, Daniels JA, Hay JE, Charlton MR, Brandhagen DJ, Rosen CB, Porayko MK. Ultrasound-assisted percutaneous liver biopsy performed by a physician assistant. Am J Gastroenterol. 2002;97:1472-5.

24. Haynes P, Liangpunsakul S, Chalasani N. Nonalcoholic fatty liver disease in individuals with severe obesity. Clin Liver Dis. 2004;8:535-47.

25. Instituto Brasileiro de Geografia e Estatística IBGE. Pesquisa de Orçamentos Familiares- POF 2002-2003. Disponível em: http://www.ibge.gov.br/home/estatistica/ populacao/condicaodevida/pof/2002aquisicao/default.shtm. Updated:2007.

26. Kleiner DE, Brunt EM, Van Natta M, Behling C, Contos MJ, Cummings OW, Ferrell LD, Liu YC, Torbenson MS, Unalp-Arida A, Yeh M, McCullough AJ, Sanyal AJ. Design and validation of a histological scoring system for nonalcoholic fatty liver disease. Hepatology. 2005;41:1313-21.

27. Liu X, Lazenby AJ, Clements RH, Jhala N, Abrams GA. Resolution of nonalcoholic steatohepatits after gastric bypass surgery. Obes Surg. 2007;17:486-92.

28. Machado M, Marques-Vidal P, Cortez-Pinto H. Hepatic histology in obese patients undergoing bariatric surgery. J Hepatol. 2006;45:600-6.

29. Nomura H, Kashiwagi S, Hayashi J, Kajiyama W, Tani S, Goto M. Prevalence of fatty liver in a general population of Okinawa, Japan. Jpn J Med. 1988;27:142-9.

30. Perrault J, McGill DB, Ott BJ, Taylor WF. Liver biopsy: complications in 1000 inpatients and outpatients. Gastroenterology. 1978;74:103-6.

31. Poynard T, McHutchison J, Manns M, Myers RP, Albrecht J. Biochemical surrogate markers of liver fibrosis and activity in a randomized trial of peginterferon alfa-2b and ribavirin. Hepatology. 2003;38:481-92.

32. Ratziu V, Giral P, Charlotte F, Bruckert E, Thibault V, Theodorou I, Khalil L, Turpin G, Opolon P, Poynard T. Liver fibrosis in overweight patients. Gastroenterology. 2000;118:1117-23.

33. Ratziu V, Massard J, Charlotte F, Messous D, Imbert-Bismut F, Bonyhay L, Tahiri M, Munteanu M, Thabut D, Cadranel JF, Le Bail B, de Ledinghen V, Poynard T. Diagnostic value of biochemical markers (FibroTest-FibroSURE) for the prediction of liver fibrosis in patients with non-alcoholic fatty liver disease. BMC Gastroenterol. 2006;14:6.

34. Sanyal AJ. AGA technical review on nonalcoholic fatty liver disease. Gastroenterology. 2002; 123:1705-25.

35. Sanyal AJ, Banas C, Sargeant C, Luketic VA, Sterling RK, Stravitz RT, Shiffman ML, Heuman D, Coterrell A, Fisher RA, Contos MJ, Mills AS. Similarities and differences in outcomes of cirrhosis due to nonalcoholic steatohepatitis and hepatitis C. Hepatology. 2006;43:682-9.

36. Spaulding L, Trainer T, Janiec D. Prevalence of non-alcoholic steatohepatitis in morbidly obese subjects undergoing gastric bypass. Obes Surg. 2003;13:347-9.

37. Stratopoulos C, Papakonstantinou A, Terzis I, Spiliadi C, Dimitriades G, Komesidou V, Kitsanta P, Argyrakos T, Hadjiyannakis E. Changes in liver histology accompanying massive weight loss after gastroplasty for morbid obesity. Obes Surg. 2005; 15:1154-60.

38. Teli MR, James OF, Burt AD, Bennett MK, Day CP. The natural history of nonalcoholic fatty liver: a follow-up study. Hepatology. 1995;22:1714-9.

39. Wai C, Greenson JK, Fontana RJ, Kalbfleisch JD, Marrero JA, Conjeevaram HS, Lok AS. A simple noninvasive index can predict both significant fibrosis and cirrhosis in patients with chronic hepatitis C. Hepatology. 2003;38:518-26.

Received 31/8/2009 Accepted 8/12/2009. 